\title{
MODEL PENGELOLAAN PEMBELAJARAN BERBASIS WEB DI SMAN 1 BAMBANGLIPURO KABUPATEN BANTUL DIY
}

\author{
Lantip Diat Prasojo, Udik Budi Wibowo \\ Universitas Negeri Yogyakarta \\ lantip1975@gmail.com, yube2u@yahoo.com
}

\begin{abstract}
Abstrak
Penelitian ini dilaksanakan berdasarkan pada studi awal peneliti yang menemukan permasalahan yang terkait dengan minimnya model pengelolaan pembelajaran berbasis web pada SMAN 1 Bambanglipuro Kabupaten Bantul DIY. Untuk memecahkan permasalahan tersebut, maka peneliti bermaksud mengadakan penelitian untuk meningkatkan kualitas pengelolaan pembelajaran berbasis web pada SMAN 1 Bambanglipuro Kabupaten Bantul DIY. Tujuan penelitian ini adalah memformulasikan model pembelajaran berbasis web dan multimedia dalam proses pembelajaran pada SMAN 1 Bambanglipuro Kabupaten Bantul DIY. Penelitian ini ingin mengembangkan model pengelolaan pembelajaran berbasis web di SMAN 1 Bambanglipuro Kabupaten Bantul DIY sebagai usaha untuk meningkatkan mutu pembelajaran yang efektif dan efisien. Adapun metode penelitian ini adalah research and development $(R \in \mathcal{E} D)$. Hasil penelitian ini adalah 1) Adanya dukungan kebijakan dari Kepala SMAN 1 Bambanglipuro Kabupaten Bantul dalam mewujudkan perbelajaran berbasis web. 2) Model pengelolaan pembelajaran berbasis di SMAN 1 Bambanglipuro Kabupaten Bantul yang berupa Software E-learning.
\end{abstract}

Kata kunci: Pengelolaan, Pembelajaran, web

\section{MODELS OF WEB-BASED LEARNING MANAGEMENT IN PUBLIC SENIOR HIGH SCHOOL 1 BAMBANGLIPURO, BANTUL, DIY}

\begin{abstract}
The research was conducted by researchers at the beginning of the study that found the problems associated with the lack of model of web-based learning management at SMAN 1 Bambanglipuro Bantul Yogyakarta. To solve these problems, the researchers intend to conduct research to improve the quality of web-based learning management at SMAN 1 Bambanglipuro Bantul Yogyakarta. The purpose of this study is to formulate a model of web-based learning and multimedia in the learning process at SMAN 1 Bambanglipuro Bantul Yogyakarta. This study would like to develop a web-based learning management model in SMAN 1 Bambanglipuro Bantul DIY in an effort to improve the quality of learning that is effective and efficient. The method of this research is the research and development $(R \mathcal{E} D)$. The results of this study were 1 ) There is support for the policy of SMAN 1 Bambanglipuro Bantul in creating web-based perbelajaran 2 ) Model -based learning management at SMAN 1 Bambanglipuro Bantul district in the form of e-learning software.
\end{abstract}

Keywords: management, learning, web 


\section{Pendahuluan}

Perkembangan teknologi multimedia telah berubah sedemikian pesat sehingga dapat merubah model pembelajara dan perkembangannya. Multimedia juga menyediakan peluang bagi dosen dan mahasiswa untuk mengembangkan teknik pembelajaran sehingga menghasilkan hasil yang maksimal. Multimedia juga sudah berkembang menjadi sebuah teknologi tersendiri. Melalui teknologi ini seorang guru dapat mengajar dengan berbagai animasi dan tampilan yang menarik. Kelihatannya teknologi ini memiliki daya tarik, efisiensi, dan efektifitas dalam membantu proses belajar mengajar. Pada masa mendatang, teknologi multimedia ini dapat menjadi sebuah solusi dan teknologi alternatif untuk digunakan dalam metode pengajaran.

Penelitian ini dilaksanakan berdasarkan pada studi awal peneliti yang menemukan permasalahan yang terkait dengan minimnya model pembelajaran berbasis multimedia pada SMAN 1 Bambanglipuro Kabupaten Bantul DIY. Sistem pembelajaran yang ada pada saat ini, berupa pembelajaran yang masih minim dengan multimedia. Hal ini dapat dilihat dengan masih jarangnya pembelajaran di sekolah-sekolah dasar negeri di Kabupaten Bantul yang menggunakan web dan multimedia. Kondisi ini diperkuat dengan terbatasnya guru-guru yang memanfaatkan multimedia dalam proses pembelajarannya karena faktor kemampuan dalam teknologi multimedia. Kondisi disebabkan belum adanya framework model pembelajaran yang berbasis multimedia. Dalam ruang lingkup internet diduga ada beberapa permasalahan antara lain informasi yang ditampilkan kadang-kadang sudah terlalu lama, perangkat lunak yang digunakan belum mengikuti perkembangan teknologi informasi.

Proses pembelajaran di SMAN 1 Bambanglipuro Kabupaten Bantul DIY sebagian besar masih menggunakan pendekatan semi web, karena keterbatasan pengembangan perangkat lunak dan perangkat keras serta SDM pendukungnya. Beberapa guru memang sudah menggunakan sistem e-learning, namun dalam implemen- tasinya masih kurang dan mengalami beberapa permasalahan, yaitu: 1) masaslah kebiajakan sekolah terkait TIK; 2) masalah dalam kesipan SDM pendukung; 3) masalah pengembangan perangkat keras dan lunak yang sesuai dengan proses pembelajaran; 4) biaya pemeliharaan atau perawatan sistem yang cukup mahal; 5) timbulnya permasalahan baru pada pihak pemakai system karena kurang terlibat pada proses pengembangan sistem. Berdasarkan permasalahan-permasalahan di SMAN 1 Bambanglipuro Kabupaten Bantul DIY sebagaimana tersebut di atas, maka perlu diadakan penelitian khusus yang berkaitan dengan pengembangan pembelajaran berbasis web dan multimedia pada SMAN 1 Kabupaten Bantul DIY.

Berdasarkan latarbelakang di atas, maka dapat dirumuskan masalah penelitian sebagai berikut: 1) Bagaimana dukungan kebijakan terkait TIK di SMAN 1 Bambanglipuro Kabupaten Bantul DIY? 2) Bagaimana memformulasikan model pengelolaan pembelajaran berbasis web pada SMAN 1 Bambanglipuro Kabupaten Bantul DIY?

Tujuan umum penelitian ini adalah memberikan sumbangan dalam pengembangan pengelolaan web dalam bidang pendidikan (menggunakan prinsip pedagogi). Sedangkan tujuan khususnya adalah 1) Mengetahui dukungan kebijakan terkait TIK di SMAN 1 Bambanglipuro Kabupaten Bantul DIY, 2) Memformulasikan model pengelolaan pembelajaran berbasis web di SMAN 1 Bambanglipuro Kabupaten Bantul DIY.

Nanang Fattah (1999: 22) mengatakan manajemen secara teoritis diklasifikasikan menjadi tiga macam yaitu (a) teori klasik; (b) teori neo klasik; (c) teori modern. Dalam konsep teori klasik berasumsi bahwa para pekerja atau manusia itu sifatnya rasional, berfikir logik, dan kerja merupakan sesuatu yang diharapkan, oleh karena itu teori klasik memulai dari premis bahwa organisasi bekerja dalam proses yang logis dan rasional dengan pendekatan ilmiah dan berlangsung terstruktur. Beberapa tokoh teori klasik adalah Fayol (1916), dengan 
lima unsur manajemen yaitu planning, organizing, accommodating, coordinating, dan controlling.

Sementara itu teori neo klasik muncul karena para ahli memandang ada beberapa kelemahan pada teori klasik. Di antara kelemahan tersebut adalah semakin kompleksnya persoalan yang dihadapi yang tidak dapat dipecahkan dengan mengikuti pola bahwa tingkah laku manusia rasional. Oleh karena itu perlu upaya untuk membantu para pengelola organisasi (pimpinan atau manajer) dalam menghadapi manusia atau pegawai dengan beragam perilaku, sehingga organisasi dapat berjalan secara efektif dan efisien. Cara yang ditempuh oleh para ahli untuk menutupi kelemahan teori klasik adalah dengan memperkuat wawasan, yang meliputi wawasan sosiologi dan psikologi. Orientasi dan pendekatan teori neo-klasik dari perluasan kedua wawasan tersebut adalah pada perilaku individu dalam organisasi. Asumsi dasar dari teori ini adalah bahwa manusia itu merupakan makluk sosial dengan mengaktualisasikan dirinya masing-masing. Beberapa tokoh dari teori neo-klasik ini antara lain: (1) Mayo, dengan studi hubungan antar manusia, atau tingkah laku manusia dalam suasana kerja, yang terkenal dengan Studi Hawthrorne; (2) McGregor, yang terkenal dengan teori $X$ dan teori Y; (3) Vromm at. al dengan teori harapan; (4) McCelland, dengan teori prestasinya, dan lain-lain (Nanang Fattah, p.1999).

Pendekatan teori modern berdasarkan hal-hal yang sifatnya situasional. Hal ini berarti orang menyesuaikan dengan situasi yang dihadapi dan mengambil keputusan sesuai dengan situasi dan kondisi lingkungannya. Asumsi yang dipakai dalam teori modern ini adalah bahwa orang itu berlainan dan berubah baik kebutuhan, reaksi, tindakan yang semuanya berubah sesuai dengan likungannya masing-masing. Selanjutnya orang bekerja dalam suatu sistem untuk mencapai tujuan bersama. Karena sistem organisasi terdiri dari individu-individu, organisasi formal, gaya kepemimpinan, perangkat keras, perangkat lunak, dan lain-lain yang mana antara satu dengan yang lainnya saling berhubungan dan berinteraksi. Pendekatan sistem dengan manajemen berusaha untuk memandang organisasi sebagai sebuah sistem yang menyatu dengan tujuan tertentu yang terdiri dari komponen-komponen yang saling berhubungan dan berinteraksi. Jadi pendekatan sistem adalah merupakan satu kesatuan dalam memandang organisasi yang tak terpisahkan dari lingkungannya (Nanang Fattah, p.1999). Salah satu tokoh teori manajemen modern adalah Dessler (2003, p.2) yang mengatakan bahwa proses manajemen melibatkan setiap fungsi: planning, organizing, staffing, leading, dan controlling.

Manajemen yang baik sangat diperlukan dalam setiap organisasi untuk menjaga kelangsungan hidup organisasi dan pengembangannya. Organisasi yang tidak memiliki sistem manajemen yang baik, maka tidak akan dapat berkembang dengan pesat bahkan mengalami kemunduran.

Ilmu pengetahuan manajemen dapat berperan dalam mengembangkan prosedur-prosedur untuk melakukan analisis dan pemecahan permasalahan dengan pemanfaatan teknologi dalam rangka mengambil suatu keputusan. Dalam kaitan dengan hal ini, Sondang P. Siagian (1985, p.30) memberikan penjelasan mengenai manajemen sebagai berikut: 1) Manajemen sebagai proses penggerakan orang lain untuk memperoleh hasil tertentu dalam rangka pencapaian tujuan yang telah ditentukan sebelumnya; 2) Manajemen dalam arti kelompok yang terdiri dari tiga tingkatan yaitu (a) Top Management, (b) Middle Management, (c) Supervisor Management; 3) Manajemen sebagai salah satu cabang ilmu pengetahuan.

Berdasarkan pengertian di atas, dapat dianalisa bahwa pengertian pertama mamandang manajemen sebagai suatu proses teknis untuk mencapai tujuan, sedangkan yang kedua lebih menekankan pada orang yang terlibat dalam proses manajemen.

Terry (1977, p.4) mendefinisikan manajemen dengan memandangnya dari su- 
dut proses, yaitu sebuah proses yang khas, yang terdiri dari tindakan-tindakan: perencanaan, pengorganisasian, penggiatan, dan pengawasan, yang yang dilakukan untuk menentukan serta mencapai sasaran-sasaran yang telah ditetapkan melalui pemanfaatan sumber daya manusia dan sumber-sumber lainnya.

Sedangkan Schermerhorn, Jr. (1997, p.4) mendefinisikan manajemen adalah proses perencanaan, pengorganisasian, pengarahan, dan pengendalian terhadap penggunaan sumber daya untuk mencapai tujuan. Jadi manajemen adalah proses apa yang harus dilakukan pimpinan untuk mencapai tujuan. Murdick (1993, pp.5-6) mengatakan bahwa manajemen terdiri dari proses atau kegiatan yang menjadikan apa yang dilakukan manajer pada operasi oragnisasi mereka yang meliputi kegiatan merencanakan, mengorganisasikan, memprakarsai, dan mengendalikan operasi. Berdasarkan pendapat para ahli sebagaimana tersebut di atas, maka dapat disimpulkan bahwa manajemen adalah proses merencana, mengorganisasi, mengarahkan, dan mengendalikan sumber daya untuk mencapai tujuan yang telah ditetapkan.

Untuk mengetahui kebutuhan manajer akan informasi dan hal-hal yang dihasilkan dalam pekerjaan, maka perlu dikelompokkan seluruh tugas atau fungsi manajemen yang telah dikemukakan oleh para ahli. Fungsi manajemen memang banyak macamnya dan selalu berkembang sesuai dengan perkembangan zaman. Penambahan atau pengurangan fungsi-fungsi manajemen ini disesuaikan dengan kebutuhan dan kondisi organisasi yang bersangkutan. Schermerhorn, Jr. (2001, pp.11-12) mengatakan fungsi-fungsi manajemen sebagai berikut: 1) Perencanaan, merupakan proses untuk menentukan tujuan yang akan dicapai serta langkah-langkah yang harus diambil untuk mencapainya; 2) Pengorganisasian, merupakan proses pemberian tugas, pengalokasian sumber daya, serta pengaturan kegiatan secara terkoordinir kepada setiap individu atau kelompok untuk menerapkan rencana; 3) Pengarahan, adalah proses untuk menumbuhkan se- mangat pada bawahan supaya bekerja giat serta membimbing mereka malaksanakan rencana dalam mencapai tujuan; 4) Pengendalian, merupakan proses pengukuran kinerja, membandingkan antara hasil sesungguhnya dengan rencana serta mengambil tindakan pembetulan yang diperlukan.

Teknologi Informasi dan Komunikasi

Sebagian besar orang memandang ICT sebagaimana pendapat Marc Marenco (2001) sebagai berikut: ...either the equipment would not do what I wanted it to do when I wanted it to do it (rather important for a professor trying to teach) or using the technology took valuable intellectual resources a way from the subject and wasted them on technology, or using the technology simply did not have the desired heuristic impact. Another reason that I have been skeptic is that I'm not convinced that what we are doing with computers and the internet isn't doing some thing we just can't quite see at this stage because we are too close to the technology.

Selanjutnya digambarkan bahwa pada intinya ICT memiliki tiga fenomena pemikiran, yaitu: 1) increasing numbers of bright; techno-component, techno-expextant student; 2) an ethernet connection in every classroom; 3) development in the direction of what is now called "opacity" in ICT.

Pengertian 'teknologi' telah diberikan antara lain oleh David L. Goetch: people tools, resources, to solve problems or to exted their capabilities. Teknologi dapat dipahami sebagai upaya untuk mendapatkan suatu 'produk' yang dilakukan oleh manusia dengan memanfaatkan peralatan (tools), proses, dan sumberdaya (resources). Teknologi bisa mencakup segala hal yang tidak terbatas hanya pada komputer, televisi, VCR, dan DVD, alat presentasi audio/visual, system satellite broadcast, alat adaptive, infrastruktur networking, operasional, dan program manajemen.

Banyak teori yang membahas tentang multimedia, namun dalam penelitian ini dibatasi beberapa teori saja karena pada subtansinya teori-teori multimedia tersebut relatif sama. Multimedia adalah penggunaan komputer untuk menyajikan dan meng- 
gabungkan teks, suara, gambar, animasi dan video dengan alat bantu dan koneksi sehingga pengguna dapat bernavigasi, berinteraksi, berkarya dan berkomunikasi (http://id.wikipedia.org/wiki/Multimedia, diunduh pada bulan maret 2011). Pendapat lain yang terkait dengan multi media adalah Clark dan Mayer (2003, p.11) mendefinisikan bahwa multimedia learning as training delivered on a computer (including $C D$ ROM, Internet, or Intranet) that is designed to support individual learning or oragnizational performance goals.

Dengan demikian dapat disimpulkan bahwa pembelajaran multimedia adalah proses pembelajaran yang memanfaatkan teknologi multimedia agar lebih menarik dan interaktif. Tujuan pemanfaatan teknologi multimedia ini adalah agar proses pembelajaran lebih mudah dipahami oleh peserta didik.

Thompson, Ganxglass dan Simon (Simamora, 2003, p. 351) mendefinisikan bahwa e-learning adalah suatu pengalaman belajar yang disampaikan melalui teknologi elektronika. Definisi lain tentang elearning disampaikan oleh Dodd (2002, p.286) adalah kegiatan belajar melalui perangkat elektronik komputer yang tersambung pada internet. Berdasarkan definisi e-learning tersebut, maka dapat disimpulkan bahwa e-learning adalah proses pembelajaran on-line dengan menggunakan ICT. Sistem e-learning dibangun dengan unsur-unsur yang sama untuk membangun teknologi informasi atau komputer. Dengan unsur-unsur tersebut sistem $e$ learning dapat berjalan dengan baik sehingga dapat mendukung proses pembelajaran. Selain itu, Onong Uchjana Effendi, (1989) membedakan tiga unsur dasar dalam sistem informasi manajemen berbasis komputer, yaitu: 1) Hardware (perangkat keras), 2) Software (perangkat lunak), dan 3) Brainware (personalia). Dengan demikian, dapat diasumsikan bahwa unsur-unsur pendukung e-learning adalah bagian-bagian yang membangun sistem e-learning yang terdiri dari hardware, software dan brainware.

Proses pembelajaran dengan menggunakan e-learning dapat memberikan be- berapa manfaat bagi dosen antara lain adalah bahwa dosen: (1) lebih mudah melakukan pemutakhiran bahan-bahan belajar yang menjadi tanggung-jawabnya sesuai dengan tuntutan perkembangan keilmuan; (2) mengembangkan diri atau melakukan penelitian guna peningkatan dan pengembangan materi perkuliahan (3) mengontrol kegiatan belajar peserta didik; (4) mengecek apakah peserta didik sudah mengerjakan soal-soal latihan sesudah mempelajari topik tertentu; dan (5) memeriksa jawaban peserta didik dan memberitahukan hasilnya kepada peserta didik. Dengan demikian, dapat diasumsikan bahwa pemanfaatan e-learning adalah kemampuan setiap dosen dalam menggunakan e-learning untuk mendukung kelancaran proses pembelajarannya (perencanaan, pengorganisasian, pengendalian, dan upload materi kuliah, tugas-tugas, dan soal-soal UTS serta UAS, diskusi ke dalam sistem e-learning).

Teknologi pembelajaran memiliki makna pemakaian prinsip-prinsip ilmiah dalam proses belajar mengajar (Gagne, 1976; Sudjana, 1989). Penggunaan teknologi khususnya teknologi informasi dapat meningkatkan kualitas pendidikan (Bates, 1995). Teknologi pembelajaran dapat membangkitkan rasa senang sehingga dapat mempengaruhi semangat, membantu memantapkan pengetahuan pada benak siswa serta menghidupkan pelajaran (Ibrahim, 1992).

Ciri-ciri manajemen abad 21 sebagaimana dikatakan Indrajit \& Djokopranoto (2006, pp.30-31) adalah sebagai berikut ini: 1) manajemen harus berhubungan dengan kompetisi global, bukan lagi lokal dan regional; 2) manajemen harus menyadari bahwa internasionalisasi sudah terdesak oleh globalisasi; 3) manajemen dewasa ini lebih berbasis teknologi, terlebih lagi teknologi informasi; 4) karyawan lebih merupakan mitra daripada bawahan; 5) para manajer harus mengelola perubahan; 6) kewiraswastaan dewasa ini tetap mendorong kemajuan ekonomi; 7) kerjasama tetap merupakan suatu kebutuhan dan keharusan; 8) keragaman harus dikelola; 9) para manajer harus mengubah budaya organisasi. 


\section{Metode Penelitian}

Jenis Penelitian

Penelitian ini bertujuan ingin mengungkap berbagai gejala dan fenomena yang ada pada pengembangan pembelajaran berbasis web di sekolah sebagai usaha utuk menemukan model pembelajaran ber-basis web dan multimedia yang efektif. Jenis metode yang dipakai dalam penelitian ini adalah metode Penelitian dan Pengembangan (Research and Development) atau sering disingkat R\&D. Alasan memilih metode ini adalah: 1) Metode R\&D dalam banyak hal sering digunakan untuk menghasilkan produk tertentu dan menguji keefektifan produk yang dihasilkan; 2) Metode R\&D ini sangat cocok untuk pengembangan bidang-bidang yang terkait dengan teknologi diklat; 3) Secara umum, tujuan dari R\&D tidak dimaksudkan untuk menguji teori, akan tetapi berorientasi untuk menghasilkan atau mengembangkan produk misalnya mengembangkan model sekolah, mengembangkan media pembelajaran, termasuk mengembangkan model juga mengembangkan model diklat (Wasis D. Dwiyogo, 2004).

Borg and Gall (2007) menyatakan R\&D adalah suatu proses yang digunakan untuk mengembangkan atau memvalidasi produk-produk yang digunakan dalam pendidikan dan pembelajaran. Artinya pendekatan R\&D ini sangat cocok untuk menilai atau memverifikasi berbagai model diklat di lembaga diklat. Berdasarkan ketiga pendapat di atas dapat ditarik suatu kesimpulan bahwa R\&D merupakan pendekatan yang paling cocok untuk pengembangan model diklat di lembaga diklat.

Waktu dan Tempat Penelitian

Penelitian ini dilakukan selama 4 bulan (Agustus s.d November 2013) di SMA N 1 Bambanglipuro, Bantul.

Prosedur

Penelitian ini bertujuan untuk menemukan model dilat kewirausahaan remaja putus sekolah yang efektif. Pelaksanaan penelitian secara garis besar dilakukan dalam dua tahap: (1) Melakukan penelitian dan mengumpulkan informasi guna merencanakan model; (2) Melakukan uji coba model diklat kewirausahaan yang efektif di lapangan. Prosedur yang akan dipakai dalam penelitian ini mengikuti sepuluh tahap R\&D yang dikembangkan oleh Borg \& Gall (2007). Dalam penelitian ini kesepuluh tahap tersebut dimodifikasi menjadi delapan tahap untuk penyesuain dengan konteks penelitian. Kedelapan tahapan tersebut adalah: 1) Penelitian dan pengumpulan informasi (research and information collecting); 2) Perencanaan (planning); 3) Mengembangkan prarencana produk (develop preliminary form of product); 4) Melakukan uji pendahuluan di lapangan (preliminary field testing); 5) Melakukan revisi produk (main product revision); 6) Melakukan uji produk di lapangan (main field testing); 7) Revisi produk akhir (final product revision); 8) Penyebaran dan pelaksanaan (dissemination and implementation).

Kedelapan tahap di atas dijelaksan oleh gambar alir tahapan penelitian yang akan dilakukan untuk menemukan Model pembelajaran berbasis multimedia.

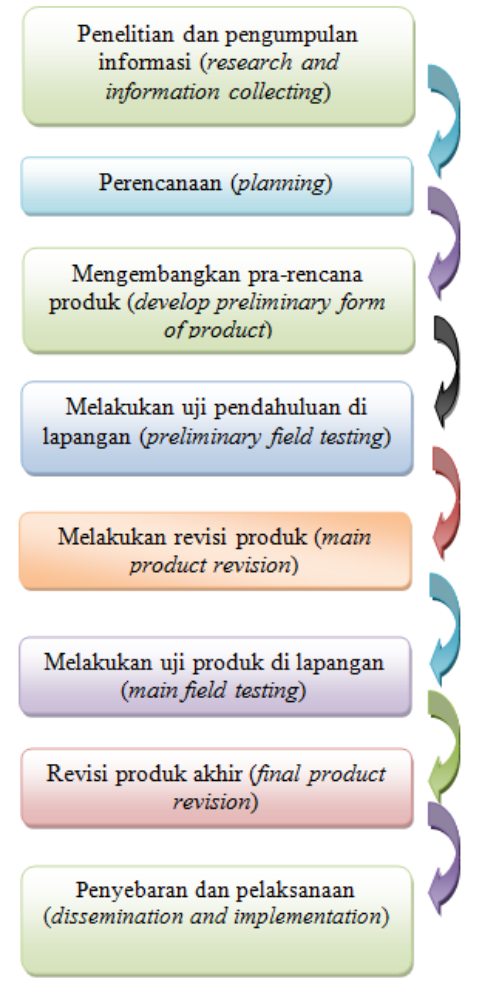

Gambar 1. Alir Tahapan Penelitian untuk Menemukan Pengembangan Model Pembelajaran Berbasis Web dan Multimedia 
Penjelasan Gambar 1 sebagai berikut.

Tahap Penelitian dan Pengumpulan Informasi (research and information collecting)

Pada tahap ini, informasi yang harus dikumpulkan adalah data dari hasil penelitian berupa informasi tentang analisis kebutuhan akan pengembangan pembelajaran berbasis web pada SMAN 1 Bambanglipuro Kabupaten Bantul DIY.

Desain penelitian kualitatif bersifat sementara (emergent) yaitu dapat diubahubah sesuai realitas sosial di lapangan. Pemilihan informan bersifat bola salju (snowball) yaitu informan bertambah terus sampai informasi yang didapat jenuh (redundancy). Informan utama adalah remaja putus sekolah yang sering terlibat dalam kegiatan diklat. Instrumen penelitian adalah peneliti sendiri (human instrument). Pengumpulan data mengunakan pendekatan inkuiri naturalistik yang meliputi pengumpulan data, penyajian data, reduksi data, analisis data, verifikasi dan penyimpulan (Miles \& Huberman, 2004). Analisis data menggunakan model Craswell (2008). Analisis data dilakukan sejak awal hingga akhir penelitian secara simultan. Penelitian menggunakan pendekatan inkuiri naturalistik karena ingin mendapatkan model pengelolaan pembelajaran yang efektif menurut yang dipikirkan dan dirasakan mereka. Pihak yang paling tahu diklat yang efektif adalah mereka sebagai pemakai.

Upaya peningkatan kredibilitas hasil penelitian dicapai melalui: (1) kegiatan, (2) diskusi dengan teman sejawat, (3) analisis kasus negatif, (4) referensi yang cukup, (5) pengecekan oleh subjek penelitian (member check) (Lincoln \& Guba, 1985). Kegiatan meliputi: memperlancar waktu penelitian, mengumpulkan data terus-menerus dengan teliti dan tekun, mengadakan triangulasi melalui berbagai sumber data, menggunakan berbagai teknik pengumpulan data, dan mengumpulkan data yang berbeda tetapi dengan tim yang padu (Zuhdi,1998).

Tranferabilitas hasil penelitian diserahkan kepada pemakai dan bersifat kontekstual. Dependabilitas hasil penelitian diupayakan dengan mendeskripsikan data sesuai dengan kenyataan di lapangan, menggunakan partisipan lokal sebagai asisten peneliti, mengadakan audit trail, mencatat data dengan menjaga jarak yang wajar (tidak terlalu intim dan tidak pula terlalu jauh) dengan responden, dan mengkonfirmasikan hasil penelitian (intersubjektif) untuk mendapatkan konsensus terhadap kebenaran hasil penelitian.

Data tersebut dipakai sebagai informasi untuk mendesain model pembelajaran berbasis multimedia pada SMAN 1 Bambanglipuro Kabupaten Bantul DIY. Tahapan penelitian dan pengumpulan informasi dilakukan tahapan-tahapan sebagai berikut ini.

Merumuskan tujuan dan manfaat hasil penelitian

Pada tahap ini langkah yang harus dilakukan adalah merumuskan tujuan penelitian, menjelaskan fungsi dan peranan hasil penelitian terhadap kepentingan pengelolaan pembelajaran dan manfaat-manfaat hasil penelitian di masa yang akan datang.

\section{Melakukan studi literatur}

Pada tahap ini langkah yang harus dilakukan adalah melakukan studi literatur yang berkaitan dengan model-model diklat yang pernah dikembangkan para pakar. Model-model tersebut berfungsi sebagai bekal peneliti untuk memasuki lokasi penelitian guna menjaring informasi yang berkaitan dengan model pengelolaan pembelajaran yang efektif yang akan didesain.

\section{Memilih latar (setting) penelitian}

Salah satu komponen penting dan memegang peranan yang penting dalam penelitian kualitatif adalah memilih latar penelitian. Latar penelitian dalam hal ini diartikan sebagai tempat kejadian atau lingkungan di mana sesuatu kegiatan dapat diarahkan untuk mencapai tujuan penelitian. Latar penelitian meliputi tempat, waktu, kejadian atau proses, dan pelaku. Penelitian harus dilakukan dalam latar yang alami atau dalam konteks sesungguhnya (wajar). Latar yang tepat untuk penelitian kualitatif adalah yang memungkinkan peneliti untuk memasukinya, ada 
gaining entry atau establishing rapport, dan dapat menjalin hubungan dengan subjek penelitian atas dasar saling percaya yaitu hubungan baik yang ditandai adanya kesesuaian, kesepakatan, persetujuan, atau kedekatan yang wajar antara peneliti dan yang diteliti (Chaedar Alwasilah, 2003) Keberhasilan memilih latar akan memudahkan peneliti dalam melakukan beberapa kegiatan termasuk menemui responden, mengumpulkan data sesuai keinginan peneliti dengan cara-cara yang mudah ditempuh. Berkaitan dengan teori tersebut, latar penelitian yang akan dilakukan dalam penelitian ini adalah dengan mengamati dan menganalisis karakteristik yang berhubungan dengan tujuan penelitian. Adapun dimensi yang terkait dengan masalah setting memerlukan penjelasan yang rinci adalah menyangkut dimensi lokasi, pelaku, dan dimensi kegiatan (Sukardi, 2005).

Prosedur Pelaksanaan Penelitian

Pengajaran

Penelitian tindakan ini dilaksanakan melalui tahapan-tahapan sebagai berikut.

\section{Tahap Persiapan}

Tahap ini bertujuan untuk mempersiapkan hal-hal yang diperlukan dalam pelaksanaan penelitian tindakan, baik berkaitan dengan materi yang disajikan dalam pembelajaran, rancangan desain penelitian, teknis pelaksanaan, serta hal-hal lain yang dimungkinkan terjadi dan perlu diantisipasi.

Kegiatan pada tahap ini meliputi: 1) Koordinasi tim (guru pengampu mata pelajaran dan dosen peneliti); 2) Penyusunan desain penelitian yang dituangkan dalam rancangan kegiatan pembelajaran (RKP); 3) Penyusunan instrumen penelitian yang diperlukan untuk mengevaluasi proses dan hasil pembelajaran, meliputi: pedoman observasi kegiatan mahasiswa dalam pembelajaran, pedoman penilaian jurnal akademik mahasiswa dan soal tes.

\section{Tahap Pelaksanaan}

Dalam tahap ini merupakan pelaksanaan pembelajaran dengan jurnal aka- demik yang didalamnya terdapat penilaian proses serta reflesi terhadap kegiatan pembelajaran tersebut. Penjabaran kegiatan tersebut meliputi: 1) Penjelasan strategi pembelajaran yang akan ditempuh bagi masing-masing mahasiswa (2 kali pertemuan $=2 \times 100$ menit); 2) Pelaksanaan kegiatan pembelajaran (12 kali pertemuan $=12 \times 100$ menit) $50 \%$ tatap muka dan $50 \%$ melalui $e$ learning; 3) Pelaksanaan pembelajaran dengan jurnal akademik secara keseluruhan meliputi kegiatan sebagai berikut; a) Penjelasan materi IPA di SD, sesuai dengan silabi; b) Pelaksanaan pembelajaran, dimana didalamnya meliputi kegiatan: Penyampaian materi dari guru, Pencatatan informasi selama pembelajaran oleh mahasiswa, Pencatatan masalah-masalah yang dihadapi selama pembelajaran hari tersebut, dan Upaya pemecahan masalah oleh mahasiswa.

Penilaian keberhasilan pembelajaran ditinjau dari segi proses maupun hasil akhir berupa nilai matapelajaran. Penilaian proses mencakup penilaian terhadap penguasaan materi yang diberikan, yang terekam dari catatan yang dihasilkan oleh mahasiswa serta ujian mid-semester. Sedangkan penilaian akhir dilakukan pada akhir pembelajaran (ujian akhir semester/ UAS).

Data, Intrumen, dan Teknik Pengumpulan Data

Dalam penelitian ini, peneliti mengumpulkan data kualitatif yang berupa kata-kata dalam bentuk deskripsi dan bukan angka-angka. Data yang dikumpulkan dalam peneltian ini adalah data-data yang berkaitan dengan Sistem e-learning di sekolah-sekolah dasar negeri di Kabupaten Bantul, perangkat keras, perangkat lunak, dan sumber daya manusia yang menjadi pendukung sistem tersebut.

Menurut Creswell, (2003, pp.185-188) prosedur pengumpulan data dibagi menjadi 4 (empat) tipe dasar, yaitu (1) observation, (2) interviews, (3) documentation, (4) audio and visual material.

Moleong, (2001, p.112) menyatakan bahwa dalam pengumpulan data harus 
melalui beberapa bagian yang sangat penting yang disebut dengan teknik penelitian. Bagian-bagian tersebut meliputi 6 (enam) macam, yaitu (1) mengetahui sumber dan jenis data, (2) manusia sebagai instrumen (3) pengamatan berperanserta, (4) wawancara, (5) catatan lapangan, dan (6) penggunaan dokumen. Dalam penelitian ini metode pengumpulan data yang digunakan adalah pengamatan, wawancara, pengumpulan dokumen (dokumentasi), pengumpulan data dengan bantuan alat-alat audio visual.

Kriteria keberhasilan

Tolok ukur keberhasilan penelitian pengembangan ini akan dilihat dari: 1) Adanya informasi tentang kebijakan yang terkait TIK di SMAN 1 Bambanglipuro Kabupaten Bantul DIY; 2) Memformulasikan model pembelajaran berbasis web pada SMAN 1 Bambanglipuro Kabupaten Bantul DIY.

\section{Hasil Penelitian dan Pembahasan}

Hasil penelitian ini berupa software model pengembangan pengelolaan pembelajaran SMAN 1 Bambanglipuro Kabupaten Bantul DIY. Penelitian ini dirancang dua tahap dengan tahap pertama hasilnya berupa software model pengeloaan pembelajaran SMAN 1 Bambanglipuro Kabupaten Bantul DIY. Untuk tahap kedua berupa implementasi dan desiminasi model pembelajaran yang dihasilkan. Dalam Bab IV ini, akan disajikan data penelitian dari hasil eksplorasi data di lapangan. Pengumpulan data yang dibutuhkan dilakukan dengan cara wawancara mendalam, pengamatan secara langsung yang dilakukan secara terus-menerus pada bagian-bagian tertentu, studi literatur dan studi dokumen pada SMAN 1 Bambanglipuro Kabupaten Bantul DIY. Data yang diperoleh berasal dari berbagai sumber yang terpercaya meliputi kepala sekolah, guru dan siswa yang terkait dengan sistem e-learning, dokumen-dokumen dan berbagai data lain yang terkait dengan sistem e-learning di SMAN 1 Bambanglipuro Kabupaten Bantul
DIY. Jumlah Guru di SMAN 1 Bambanglipuro Kabupaten Bantul DIY adalah 43 Orang. Jumlah guru laki-laki 22 orang, guru perempuan 21 orang dengan pendidikan terendah Diploma Tiga (D3) dan pendidikan tertinggi Strata Dua (S2). Adapun jumlah siswa kelas X adalah 163 orang, kelas XI berjumlah 154 orang, dan kelas XII berjumlah 135 orang sehingga total jumlah siswanya 452 orang siswa. Selain itu terdapat Penyajian data ini untuk menjawab pertanyaan penelitian yang berkembang secara empirik di lapangan. Sistematika uraian secara lengkap dari data penelitian ini mengacu pada rumusan masalah. Adapun substansi dari pertanyaan-pertanyaan penelitian tersebut adalah (1) Bagaimana dukungan kebijakan yang terkait TIK di SMAN 1 Bambanglipuro Kabupaten Bantul DIY, 2) Bagaimana formulasi model pembelajaran berbasis web pada SMAN 1 Bambanglipuro Kabupaten Bantul DIY.

Dukungan Kebijakan dalam

Penyelenggaraan Sistem E-learning di SMKN 1 Bambanglipuro Kabupaten Bantul DIY

Dukungan kebijakan dari Pimpinan SMKN 1 Bambanglipuro Kabupaten Bantul DIY dari adanya program-program pelatihan-pelatihan terkait TIK. Selain itu, kepala sekolah mendukung pengembangan pembelajaran berbasis TIK dengan mengembangkan laboratorium komputer untuk pembelajaran siswa dengan jumlah komputer 80 buah. Jaringan komputer dan Wifi juga sudah terpasang di SMKN 1 Bambanglipuro Kabupaten Bantul DIY. Dari sisi brainware kepala sekolah juga memperhatikan dengan merekrut teknisi yang memiliki keahlian TIK.

Kebijakan terkait dengan pengembangan pembelajaran berbasis TIK juga masuk ke dalam RKAS tahun 2013. Berdasarkan RKAS tahun 2013 tersebut, kepala sekolah dan jajarannya berusaha mengembangkan pembelajaran berbasis TIK. Dengan demikian dukungan kebijakan yang ada di SMKN 1 Bambanglipuro Kabupaten Bantul DIY sudah dilakukan dari sisi hardware, brainware dan akan dilakukan 
pengembangan software pembelajaran. Dengan adanya penelitian ini dapat mendukung pengembangan software pembelajaran yang sudah direncanakan oleh Kepala SMKN 1 Bambanglipuro Kabupaten Bantul DIY.

Perangkat lunak yang dikembangkan untuk pembelajaran berbasis Web di SMKN 1 Bambanglipuro Kabupaten Bantul DIY dengan sistem E-learning

Model perangkat lunak e-learning yang dikembangkan ini berbasis web dengan database $M y$ Sql dengan program moodle. Perangkat lunak ini dikembangkan untuk pembelajaran berbasis web di SMKN 1 Bambanglipuro Kabupaten Bantul DIY dengan sistem e-learning. Perangkat lunak e-learning dirancang untuk komputer stand alone sehingga memudahkan Bapak/ Ibu Guru SMKN 1 Bambanglipuro Kabupaten Bantul DIY dalam berlatih memanfaatkan e-learning sebagai admin. Dengan posisi sebagai admin dalam sistem e-learning, maka Bapak/Ibu Guru SMKN 1 Bambanglipuro Kabupaten Bantul DIY dapat leluasa dalam mengelola sistem e-elarning sehingga ketika menggunakan pembelajaran berbasis web (e-learning) dapat berjalan dengan lancar. Berikut tampilan perangkat lunak E-learning SMKN 1 Bambanglipuro Kabupaten Bantul DIY.

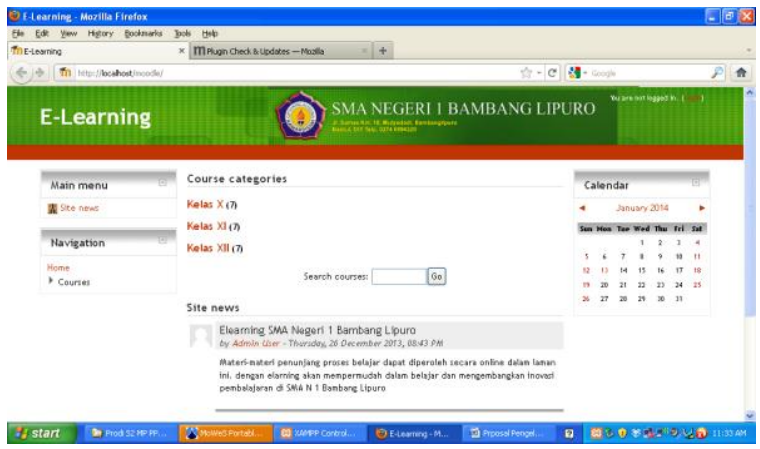

Gambar 2. Tampilan Pengembangan ELearning SMAN 1 Bambanglipuro Kabupaten Bantul DIY

Setelah dilakukan validasi perangkat lunak, software e-learning tersebut dilakukan perbaikan dan hasilnya sebagai mana gambar 2. Validasi ahli sudah dilakukan melalui validasi ahli programmer di UPT Puskom UNY.

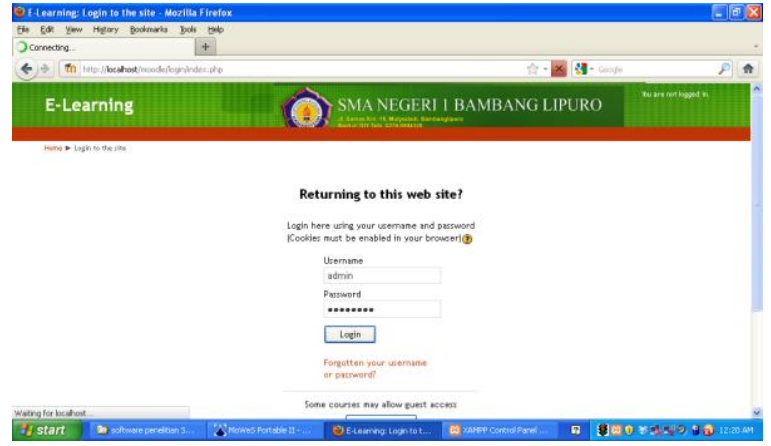

Gambar 3. Tampilan Login Pengembangan ELearning SMAN 1 Bambanglipuro

Kabupaten Bantul DIY

Gambar 3 merupakan tampilan Login Pengembangan E-Learning SMKN 1 Bambanglipuro Kabupaten Bantul DIY. Untuk melakukan pengelolaan pembelajaran berbasis web harus masuk ke login dulu dengan cara memasukan ID dan password sebagai admin. Setelah login sebagai admin maka tampilannya akan seperti gambar dibawah ini. Dalam tampilan softwarenya terdapat menu-menu yang bisa digunakan admin untuk mengelola perangkat lunak tersebut.

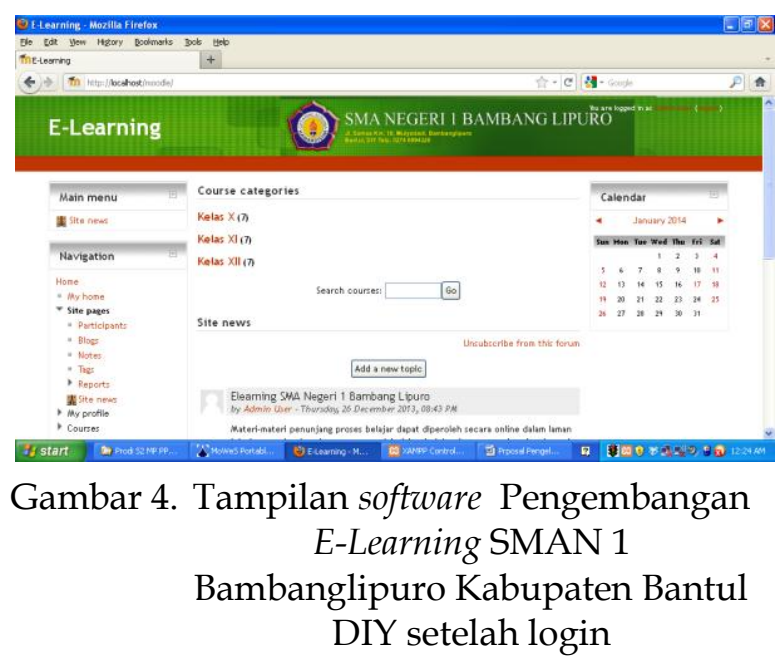

Admin dapat melakukan pengelolaan terhadap software tersebut dengan meng-gunakan menu-menu yang tersedia. Menu utama dalam pengelolaan adalah Main Menu dan Navigation. Sebagai contoh admin juga dapat membuat course di software tersebut dan hasilnya dapat diliat dalam tampilan gambar di bawah ini 


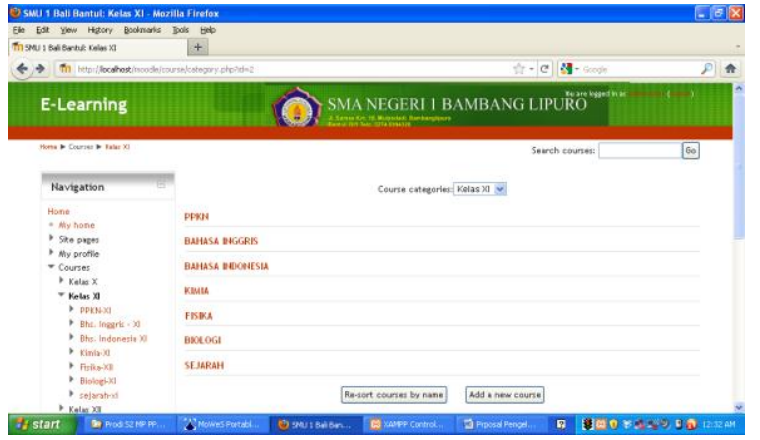

Gambar 5. Tampilan Pembagian Course

Pengembangan E-Learning SMAN

1 Bambanglipuro Kabupaten Bantul DIY

Setelah membuat course langkah berikutnya memasukan materi matapelajarannya ke course yang sudah dibuat. Dalam penelitian ini matapelajaran yang diambil adalah Matapelajaran Biologi karena objek materi yang dikembangkan dalam software ini materi Biologi. Adapun tampilan software yang sudah diisi dengan Matapelajaran Biologi seperti gambar di bawah ini.

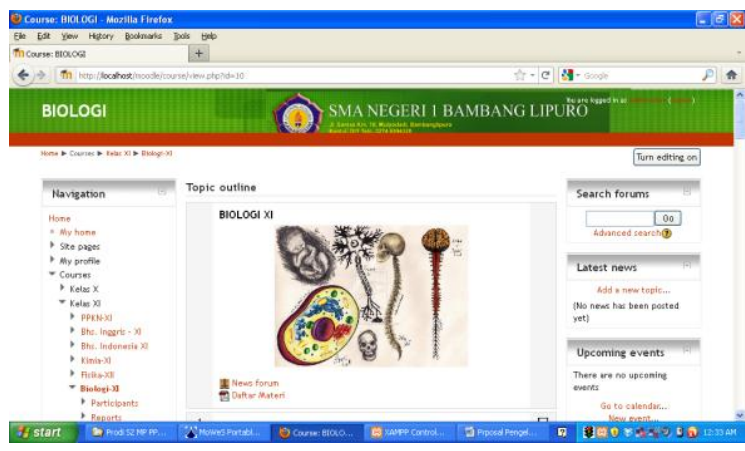

Gambar 6. Tampilan Course dengan materinya dalam sistem E-Learning SMKN 1 Bambanglipuro Kabupaten Bantul DIY

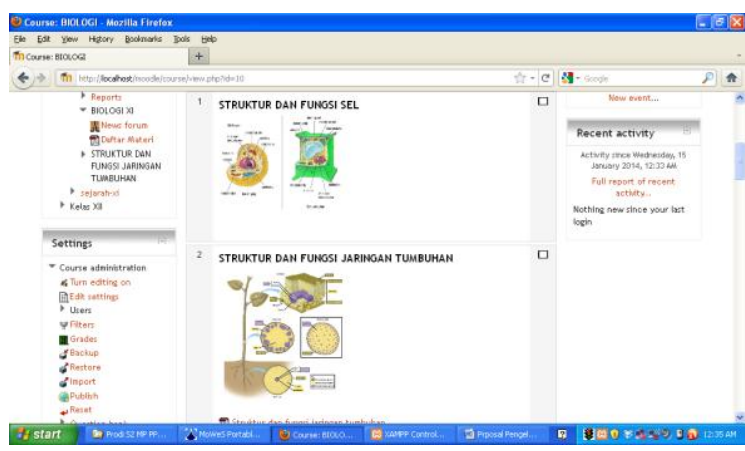

Gambar 7. Tampilan Course dengan materi struktur dan fungsi sel dalam sistem E-Learning SMAN 1

Bambanglipuro Kabupaten Bantul DIY setelah login

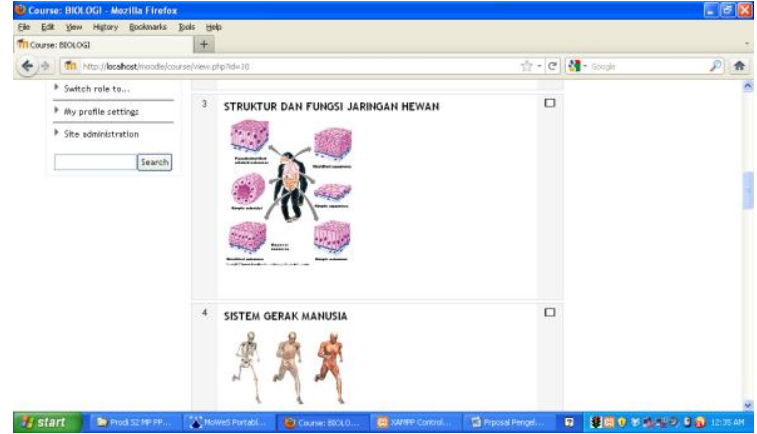

Gambar 8. Tampilan Course dengan materi struktur dan fungsi sel jaringan hewan dalam sistem E-Learning SMAN 1 Bambanglipuro Kabupaten Bantul DIY

\section{Simpulan dan Saran}

Simpulan

Model pengelolaan pembealajaran berbasis web diformulasikan dalam bentuk Software E-Learning SMKN 1 Bambanglipuro Kabupaten Bantul DIY dikembangkan dengan menggunakan open source Moodle. Perangkat lunak ini berupa framework sehingga memungkinkan guru-guru untuk mengembangkannya sendiri untuk kebutuhan proses pembelajaran terutama pengembangan matapelajaran. Posisi pengguna dalam perangkat lunak ini dapat berfungsi sebagai admin sehingga sangat memungkinkan untuk mengelola secara penuh dan mengembangkannya dalam rangka mendukung proses pembelajaran.

Saran

Perangkat lunak yang dikembangkan ini perlu dilanjutkan untuk mengimplementasikan dan desiminasi model Pengembangan E-Learning SMKN 1 Bambanglipuro ke SMK lain di Kabupaten Bantul DIY. Untuk proses implementasi dan desiminasi perlu dilakukan penelitian pada tahun berikutnya agar tingkat kebermanfaatannya bisa dirasakan SMK lainnya.

\section{Daftar Pustaka}

Anonim. (2011). Multimedia. Diambil pada Maret 2011 dari http://www.wiki pedia.com/multimedia. 
Borg, W.R., \& Gall, M.D. 2007. Educational Research: An Introduction. New York: Longman.

Chaedar Alwasilah, 2003. Pokoknya Kualitatif. Dasar-dasar Merancang dan Melakukan Penelitian Kualitatif. Bandung: PT. Dunia Pustaka Jaya.

Clark, R. C. \& Mayer, R. E. (2003). Elearning and the science of instruction. San Francisco: Jossey-Bass/Pfeiffer.

Creswell, J. W. (2003). Research design: Qualitative, quantitative and mixed methods approaches (2th ed.). Thousand Oaks, California: SAGE Publications, Inc.

Dodd, A.Z. (2002). The Essential Guide to Telecommunications. Yogyakarta: Penerbit Andi Offset.

Dessler, G. (1997). Human resource management ( $7^{\text {th }}$ ed.). Upper Saddle River, New Jersey: Prenticehall.

Moleong, L. J. (1999). Metodologi penelitian kualitatif. Bandung: Remaja Rosda Karya.

Nanang Fattah. (1999). Landasan manajemen pendidikan. Bandung: Remaja Rosda Karya.

Onong Uchjana Effendi. (1989). Sistem informasi manajemen. Bandung: Mandar Maju.
Patton, M. Q. (1997). Qualitatif evalution methods. Baverly Hills, California: Sage Publications, Inc.

Pressman, R. S. (1997). Software engineering: A practitioner's approach (4th ed.). New York St. Luis San Francisco Auckland: The McGraw-Hill Companies, Inc.

Spradley, J. P. (1980). Participant observation. New York: Holt, Rinehart and Winston.

Simamora, L. (2003). E-learning: Konsep dan Perkembangan Teknologi yang Mendukungnya.Cakrawala Pendidikan, E-learning dalam Pendidikan. Jakarta: Universitas Terbuka.

Schermerhorn, John R., Jr. (2001). Management. (Terjemahan M. Purnama Putranto) Yogyakarta: ANDI Yogyakarta.(Buku asli diterbitkan tahun 1996).

Siagian, S. P. (1985). Teori dan praktek kepemimpinan. Jakarta: PT. Rineka Cipta. . (1999). Sistem informasi manajemen. Edisi kedua. Jakarta: Bumi Aksara. . (2001). Sistem informasi manajemen untuk pengambilan keputusan. Bandung: Remadja Karya. 